\title{
Erratum to: Correlation between S-1 treatment outcome and expression of biomarkers for refractory thymic carcinoma
}

\author{
Yusuke Okuma ${ }^{1,2^{*}}$, Yukio Hosomi ${ }^{1}$, Shingo Miyamoto ${ }^{3}$, Masahiko Shibuya' ${ }^{1}$, Tatsuru Okamura ${ }^{1}$ \\ and Tsunekazu Hishima ${ }^{4}$
}

\section{Erratum}

Following publication of this work [1] the authors noticed a mistake within the article's competing interests section. The correct competing interests section is provided below.

\section{Competing interests}

The authors declare that they have no competing interests. This study is supported by the grant for the Clinical Research of Tokyo Metropolitan Hospital and Taiho Pharmaceutical Inc. who analyzed the thymidine synthase, thymidine phosphorylase, orotate phosphoribosyltransferase, and dihydropyrimidine dehydrogenase using RT-PCR.

\section{Author details}

'Department of Thoracic Oncology and Respiratory Medicine, Tokyo Metropolitan Cancer and Infectious diseases Center Komagome Hospital, 3-18-22 Honkomagome, Bunkyo, Tokyo 113-8677, Japan. 'Division of Oncology, Research Center for Medical Sciences, The Jikei University School of Medicine, Minato, Tokyo, Japan. ${ }^{3}$ Department of Clinical Oncology, Japan Red Cross Medical Center, Shibuya, Tokyo, Japan. ${ }^{4}$ Department of Pathology, Tokyo Metropolitan Cancer and Infectious diseases Center Komagome Hospital, Bunkyo, Tokyo, Japan.

Received: 11 April 2016 Accepted: 11 April 2016

Published online: 15 April 2016

\section{Reference}

1. Okuma Y, Hosomi Y, Miyamoto S, Shibuya M, Okamura T, Hishima T.

Correlation between S-1 treatment outcome and expression of biomarkers for refractory thymic carcinoma. BMC Cancer. 2016;16:156. doi:10.1186/ s12885-016-2159-7.

\footnotetext{
* Correspondence: y-okuma@cick.jp

'Department of Thoracic Oncology and Respiratory Medicine, Tokyo Metropolitan Cancer and Infectious diseases Center Komagome Hospital, 3-18-22 Honkomagome, Bunkyo, Tokyo 113-8677, Japan

${ }^{2}$ Division of Oncology, Research Center for Medical Sciences, The Jikei

University School of Medicine, Minato, Tokyo, Japan
}

Submit your next manuscript to BioMed Central and we will help you at every step:

- We accept pre-submission inquiries

- Our selector tool helps you to find the most relevant journal

- We provide round the clock customer support

- Convenient online submission

- Thorough peer review

- Inclusion in PubMed and all major indexing services

- Maximum visibility for your research

Submit your manuscript at www.biomedcentral.com/submit

\section{() BioMed Centra}

